the life expectancy should be shorter in Sweden than in Britain. Morris (1969) calculated life expectancy at weaning for a hedgehog population in England to be 1.9 years. Using capture-recapture data from a population in Scania I have found the corresponding value to be slightly more than two years i.e. almost the same (Kristiansson, unpubl.), which does not agree with the predictions made by Spencer \& Steinhoff (1968).

Acknowledgements: I thank Drs Sam Erlinge and Johnny Karlsson for comments on the manuscript. Mr. Jonathan Thorntorn corrected my English. The study was supported by the Swedish Society for the Conservation of Nature and World Wildlife fund.

\title{
REFERENCES
}

Deanesly R., 1934: The reproductive processes of certain mammals. Part 6: The reproductive cycle of the female hedgehog. Phil. Trans. Lond. Ser. B., 223: 239-276. - Morris B., 1967: The European hedgehog. [In: The UFAW Handbook on the care and management of laboratory animals]. 3rd ed. E. \& S. Livingstone Ltd: 478-488. Edinburgh. - Morris P. A., 1969: Some aspects of the ecology of the hedgehog (Erinaceus europeaus L.) Ph. D. Thesis. University of London. Morris P. A., 1977: Pre-weaning mortality in the hedgehog (Erinaceus europaeus L.). J. Zool., Lond, 182: 162-167. - Ranson R. M., 1941: New laboratory animals from wild species. Breeding a laboratory stock of hedgehogs (Erinaceus europaeus L.). J. Hyg. Camb., 41: 131-138. - Spencer A. W. \& Steinhoff H. W., 1968: An explanation of geographic variation in litter size. J. Mammal. 49: 281-286.

Accepted, May 14, 1981.

\section{Longevity Record for the Lesser Horseshoe Bat}

REKORDOWY WIEK PODKOWCA MAEEGO

Wincenty HARMATA

Harmata, W., 1981: Longevity record for the lesser horseshoe bat. Acta theriol., 26, 34: 507.

A ringed individual of Rhinolophus hipposideros (Bechstein, 1800) was recaptured 21 years, 3 months and 16 days after the ringing date.

[Dept. Zoopsych. Ethol. Anim., Jagiellonian Univ., Karasia 6, 30-060 Kraków].

A female lesser horseshoe bat, Rhinolophus hipposideros (Bechstein, 1800 ), with ring No. 8785 Inst. Psych. Anim. Univ. Kraków Polon. was caught on December 20th 1980 at Nietoperzowa Cave near Ojców $\left(50^{\circ} 11^{\prime} \mathrm{N}, 19^{\circ} 46^{\prime} \mathrm{E}\right)$. The bat was hanging at a height of $1.5 \mathrm{~m}$ on the cave wall, about $100 \mathrm{~m}$ from the entrance, and there were another individuals near it. The bat had been ringed on Nov. 4th 1959 in the Czerna monastery near Krzeszowice, about $15 \mathrm{~km}$ from the place at which it was found again. The animal had thus lived for 21 years, 3 months and 16 days from the date of ringing. The greatest age hitherto known, established in the same way, was 18 years and 3 months (Gaisler J. \& Hanak V., 1969: Acta Sci. Nat. Acad. Sci. Bohemosl., 3, 5: 3-33). 